\title{
Simulasi Numerik Aliran Tiga Dimensi Melalui Rectangular Duct dengan Variasi Bukaan
}

\author{
Damper
}

\author{
Edo Edgar Santosa Putra dan Wawan Aries Widodo \\ Jurusan Teknik Mesin, Fakultas Teknologi Industri, Institut Teknologi Sepuluh Nopember (ITS) \\ Jl. Arief Rahman Hakim, Surabaya 60111 Indonesia \\ e-mail:wawanaries@me.its.ac.id
}

\begin{abstract}
Abstrak - Dalam sistem saluran terdapat banyak penggunaan elbow dan assesoris lain yang akan menyebabkan terjadinya kerugian tekanan pada aliran. Hal tersebut disebabkan karena adanya perubahan arah aliran fluida yang melalui saluran tersebut. Nilai penurunan tekanan (pressure drop) pada aliran yang melalui suattu saluran dipengaruhi oleh besarnya laju aliran pada inlet, serta radius kelengkungan dari elbow yang akan menyebabkan aliran sekunder kemudian timbul aliran vortex. Hal ini berakibat kerugian energi (headloss) yang lebih besar. Peletakan bodi pengganggu dan pemasangan elbow dimaksudkan untuk melihat fenomena aliran di sekitar bodi pengganggu

Model uji yang akan digunakan di dalam studi ini berupa rectangular duct yang pada bagian inlet terpasang elbow $90^{\circ}$ dengan damper yang diletakkan pada jarak $x / D_{h}=2$. Fluida kerjanya adalah udara yang mengalir secara incompressible, viscous, steady dan mempunyai profil kecepatan uniform pada sisi inlet dengan dua variasi bilangan Reynolds yaitu $2.05 \times 10^{5}$ dan $8.2 \times 10^{5}$ serta empat pengaturan sudut bodi pengganggu $0^{\circ}, 1^{\circ}, 2^{\circ}$, dan $30^{\circ}$ Penelitian dilakukan secara numerik 3D menggunakan piranti lunak Computation Fluid Dynamics (CFD) komersial dengan model turbulensi $k-\varepsilon$ Realizable.
\end{abstract}

Hasil studi ini diperoleh bahwa proses recovery aliran dipengaruhi oleh sudut bukaan damper, untuk variasi sudut bukaan damper $30^{\circ}$. Dengan sudut bukaan $30^{\circ}$ terjadi percepatan aliran pada daerah dekat dinding yang berakibat bertambahnya momentum aliran sehingga mempercepat proses recovery aliran dan aliran sekunder pada daerah dekat dinding dapat teratasi.

Kata Kunci-Ducting, elbow, pressure drop, aliran sekunder, head loss, vortex, damper

\section{PENDAHULUAN}

$\mathrm{J}$ ARINGAN perpipaan merupakan instalasi yang sangat memegang peranan penting guna mendukung sebagian besar proses yang ada di industri, seperti yang kita ketahui pada pembangkit listrik, kilang minyak, distribusi gas alam, system pengondisian udara, dan lain-lain. Dalam system perpipaan selalu ada komponen yang disebut fitting, yang mempunyai koefisien losses dan menyebabkan pressure drop sepanjang aliran. Pada aplikasi tertentu diperlukan suatu system distribusi guna mengalirkan fluida dari suatu tempat ke tempat lain. Sepanjang system tersebut terdapat saluran pembelokan (elbow), semakin banyak belokan sepanjang saluran maka akan timbul kerugian energi yang semakin besar pula digunakan untuk mengalirkan fluida, juga guna menghendaki adanya pengaturan laju aliran massa, maka aliran tersebut pasti akan melewati suatu gangguan yang mungkin dapat menambah kerugian energi, artinya diperlukan energi yang besar untuk menanggulangi setiap kerugian yang terjadi di sepanjang instalasi.

Upaya dalam mengamati fenomena aliran pada saluran berbentuk octogonal elbow $90^{\circ}$ dengan radius ratio $\left(\mathrm{r}_{\mathrm{m}} / \mathrm{D}_{\mathrm{h}}\right)$ 1.875 sudah dilakukan oleh [1]. Penelitian ini dilakukan dengan penambahan satu buah guide vane dan tanpa guide vane. Hasil yang didapatkan pada studi eksperimen dan numerik didapatkan profil kecepatan maksimum elbow berada pada sisi inner yang kemudian bergeser menuju outer seiring dengan semakin besarnya $x / D h$ dan $\Delta C p$ antara inlet dan outlet elbow secara tidak langsung menunjukkan koefisien minor losses (K) pada elbow, dengan semakin kecilnya nilai koefisien minor maka semakin kecil juga nilai headloss pada elbow tersebut. Demikian juga pada peneliti [2] melakukan eksperimen pada pipa lurus yang diganggu oleh butterfly valve. Pipa tersebut memiliki diameter $0,3 \mathrm{~m}$ dan panjang 11D . Pengambilan data dilakukan pada bilangan Reynolds yang bervariasi rentangnya $5.0 \times 10^{4}<\operatorname{Re}<10^{6}$, dilakukan dengan tambahan elbow $90^{\circ}$ dan butterfly valve yang disetting kemiringan $0^{\circ}$ (fully open) dan $30^{\circ}$. Hasil yang didapat melalui grafik profil kecepatan pada pipa lurus yang terdapat valve bahwa aliran akan mencapai fully developed lebih awal dari pada pipa lurus yang ditambahkan elbow, hal ini disebabkan karena pada elbow tersebut sudah terjadi aliran sekunder sebelum melalui valve.

Penelitian yang dilakukan [3] adalah melakukan perbandingan antara hasil simulasi dan ekperimen. Simulasi ini dilakukan pada $\mathrm{Re}=40000$ menggunakan model turbulen RSM (Reynolds Stress Model) dengan variasi tiga kerapatan mesh yaitu, $\mathrm{Vk}_{\mathrm{I}}=553052, \mathrm{Vk}_{\mathrm{II}}=$ 1766079 , and $\mathrm{Vk}_{\mathrm{III}}=1034775$, menghasilkan data berupa grafik profil kecepatan untuk lokasi $\mathrm{x} / \mathrm{Dh}=1.0$ terdapat perbedaan signifikan pada masing-masing variasi kerapatan mesh dan yang mendekati hasil eksperimen yaitu pada jumlah mesh 1034775 .

Dari beberapa penelitian di atas dilakukan penelitian lebih lanjut tentang karakteristik aliran melewati saluran 
seperti yang dilakukan [1] dan [3] yaitu saluran yang akan dipasang elbow dan damper pada sisi inlet. Penelitian dilakukan menggunakan metoda komputasi pada bilangan Reynolds, $2.05 \times 10^{5}$ dan $8.2 \times 10^{5}$ damper diletakkan pada rasio jarak $\mathrm{x} / \mathrm{D}_{\mathrm{h}}=2$ dengan variasi bukaan damper $0^{\circ}, 10^{\circ}$, $20^{\circ}$, dan $30^{\circ}$. Hasil yang diamati berupa profil kecepatan, dan visualisasi aliran

Penelitian ini bertujuan untuk melakukan simulasi numerik aliran melalui saluran udara rectangular yang tersusun atas straight channel upstream, elbow, dan straight channel downstream yang ditempatkan sebuah damper, selanjutnya mengetahui profil kecepatan pada setiap cross section pada posisi setelah damper, mengetahui profil kecepatan sebelum elbow, pada elbow, dan setelah elbow, serta memberi gambaran tentang visualisasi aliran pada posisi setiap penampang setelah damper.

\section{METODOLOGI PENELITIAN}

Pada bab ini akan dibahas mengenai metode penelitian secara numerik yang akan digunakan. Metode ini menggunakan piranti lunak simulasi CFD komersial untuk menganalisis karakteristik aliran tiga dimensi dalam rectangular ducting dengan variasi sudut bukaan damper $0^{\circ}, 10^{\circ}, 20^{\circ}$, dan $30^{\circ}$ yang terletak pada daerah downstream setelah elbow $\mathrm{x} / \mathrm{Dh}=2$ dan besar kecepatan pada sisi inlet 10 dan $40 \mathrm{~m} / \mathrm{s}$.

\subsection{Geometri Ducting}

Ducting pada penelitian ini memiliki penampang rectangular, dan pada bagian inlet terhubung elbow 90, kemudian terpasang juga bodi pengganggu berupa damper yang terletak pada jarak $\mathrm{x} / \mathrm{D}_{\mathrm{h}}=2$ sesudah elbow. Geometri ducting dan penempatan damper diilustrasikan oleh gambar 1. Spesifikasi dari domain pemodelan ini adalah sebagai berikut:

- Bentuk Penampang

: Rectangular

- Panjang downstream duct $\left(L_{o}\right)$

: $6000 \mathrm{~mm}$

- Panjang upstream duct $\left(\mathrm{L}_{\mathrm{i}}\right)$

$: 1800 \mathrm{~mm}$

- Tinggi dan lebar $(a x b)$

- Elbow Inner radius $\left(r_{i}\right)$

: $300 \times 300 \mathrm{~mm}$

- Elbow Outer radius $\left(r_{o}\right)$

- Hydraulic diameter $\left(D_{h}\right)$

: $300 \mathrm{~mm}$

: $600 \mathrm{~mm}$

: $300 \mathrm{~mm}$

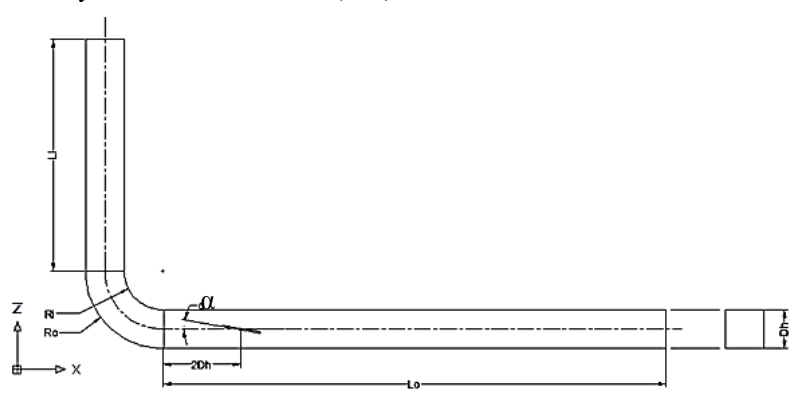

Gambar 1. Geometri Ducting
3.2. Metode Numerik

Tabel 1.

Kondisi batas dan setting awal pada metode numerik

\begin{tabular}{|c|c|c|}
\hline \multirow[b]{2}{*}{ Pre-Processing } & Tipe Mesh & Hexahedral-Map \\
\hline & Boundary Condition & $\left.\begin{array}{l}\text { Inlet : Velocity Inlet } \\
\text { Outlet : Outflow } \\
\text { Upstream Duct } \\
\text { Downstream Duct } \\
\text { Elbow }\end{array}\right\}$ Wall \\
\hline \multirow{7}{*}{ Post-Processing } & Solver & Pressure-Based \\
\hline & Model Turbulen & k-E Realizable \\
\hline & Material & $\begin{array}{l}\rho=1,225 \mathrm{~kg} / \mathrm{m}^{3} \\
\mu=1,7894 \times 10^{-5} \mathrm{~N} . \mathrm{s} / \mathrm{m}^{2} .\end{array}$ \\
\hline & Residual & $10^{-6}$ \\
\hline & Initial Condition & Velocity Inlet \\
\hline & Velocity & $10 \mathrm{~m} / \mathrm{s}$ dan $40 \mathrm{~m} / \mathrm{s}$ \\
\hline & Operating Condition & $1 \mathrm{~atm}$ \\
\hline
\end{tabular}

Untuk mengetahui geometri domain secara isometric dapat ditunjukkan melalui gambar 2 .

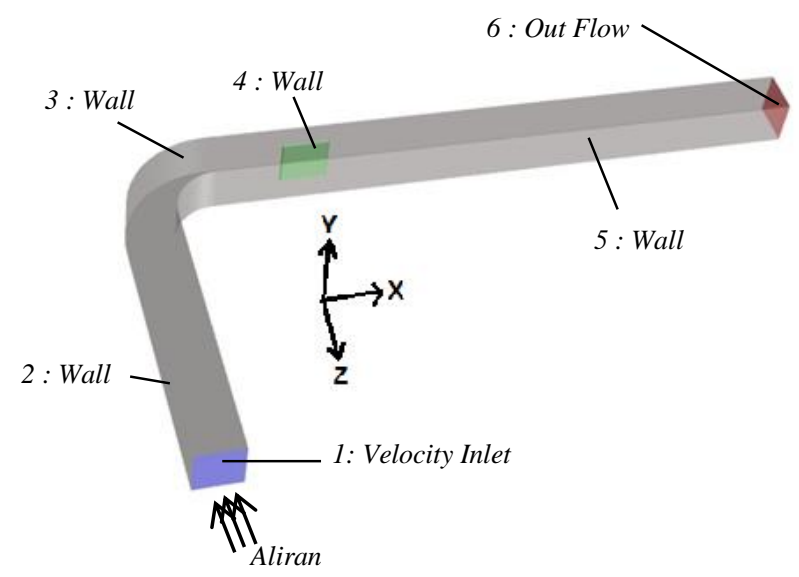

Gambar 2. Domain pemodelan dan kondisi batas dari ducting

Nomenklatur :

1. Inlet

2. Upstream Straight Channel

3. Rectangular Elbow $90^{\circ}$

4. Damper

5. Downstream Straight Channel

6. Outlet

\subsection{Posisi Pengambilan Data pada Domain Benda Uji}

Mengacu dari gambar 3. menunjukkan posisi pengambilan data profil kecepatan pada sisi downstream dan koefisien tekanan pada elbow. Referensi nol pada sisi downstream terletak di $\mathrm{x} / \mathrm{Dh}=2$. Pengambilan data profil kecepatan sisi downstream diambil di posisi $\mathrm{x} / \mathrm{Dh}=-1$ dan $\mathrm{x} / \mathrm{Dh}=1 \mathrm{~s} / \mathrm{d} \mathrm{x} / \mathrm{Dh}=15$. Pada elbow, data diambil di posisi $\varphi=0^{\circ} ; \varphi=30^{\circ} ; \varphi=60^{\circ} ;$ dan $\varphi=90^{\circ}$ baik sisi inner maupun outer wal

\section{ANALISA DAN PEMBAHASAN}

3.1. Perbandingan Distribusi Profil Kecepatan Pada Sudut Kemiringan $\alpha=0^{\circ}$ dan $30^{\circ}\left(\operatorname{Re}=2.05 \times 10^{5}\right)$

Profil Kecepatan pada ducting dipengaruhi oleh sudut kemiringan damper sebagai bodi pengganggu kemudian 
diamati perkembangan aliran di dalamnya. Distribusi kecepatan disajikan dalam bentuk kecepatan tak berdimensi $(u / U)$ dimana $u$ adalah kecepatan lokal pada section tersebut dan $U$ merupakan kecepatan maksimum pada section yang sama. Berikut ini akan dibahas perkembangan velocity profile setiap section sebagaimana yang tertera pada gambar 4. Penempatan setiap cross section dapat dilihat pada gambar 3

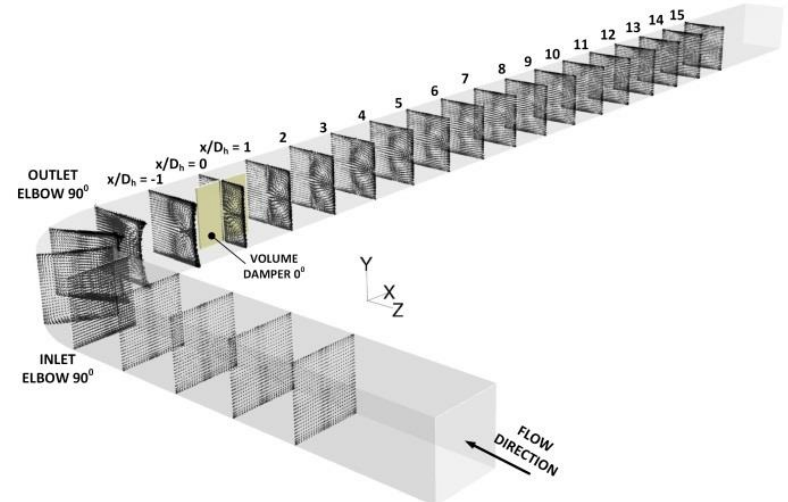

Gambar 3. Penempatan posisi cross-section

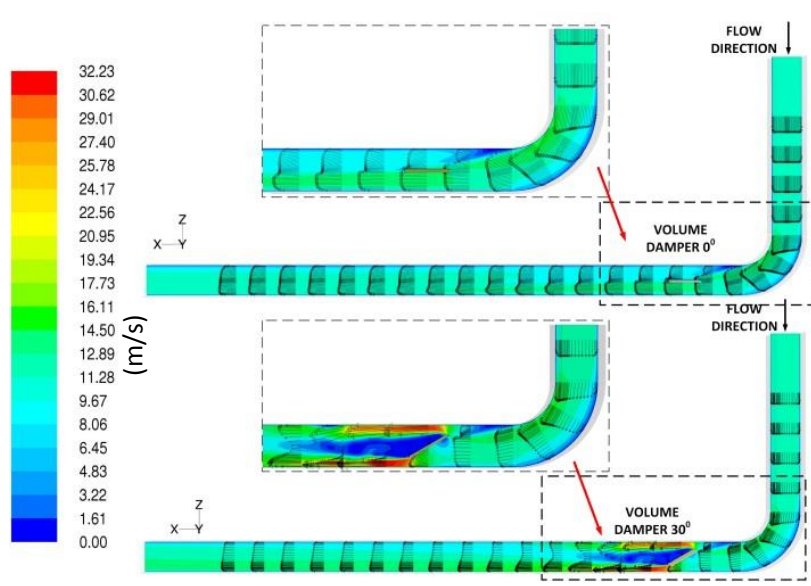

Gambar 4. Perkembangan velocity profile dan kontur kecepatan sepanjang aliran untuk $\mathrm{Re}=2.05 \times 10^{5}$

Untuk lebih jelasnya, dari gambar 4 akan dibahas penjelasan analisa tentang bagaimana perilaku aliran dua dimensi dari upstream menuju downstream berupa grafik velocity profile dalam bentuk bilangan tak berdimensi yang bernilai dari nol sampai satu baik pada absis maupun ordinat. Absis pada grafik menunjukkan posisi titik dimana nilai $\mathrm{Z} / \mathrm{h}=0.5$ adalah posisi yang searah dengan sisi inner elbow, sedangkan $\mathrm{Z} / \mathrm{h}=-0.5$ adalah posisi yang searah dengan sisi outer elbow. Pemaparan grafik perbandingan antara sudut bukaan $0^{\circ}$ dan $30^{\circ}$ sebagaimana yang tertera pada gambar 5

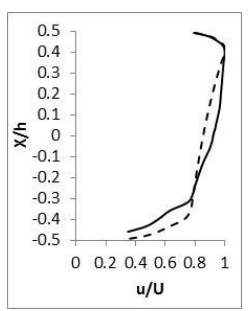

(a)

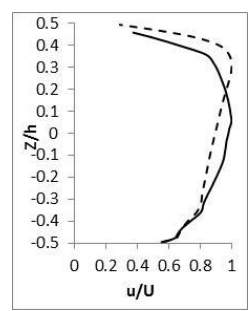

(b)

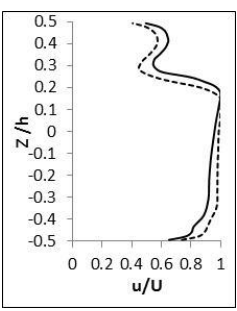

(c)

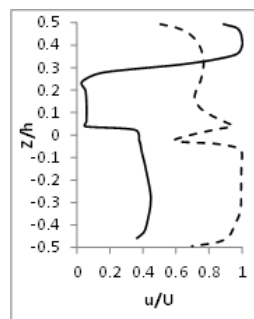

(d)

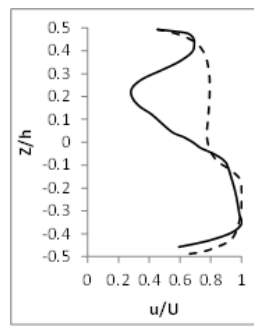

(g)

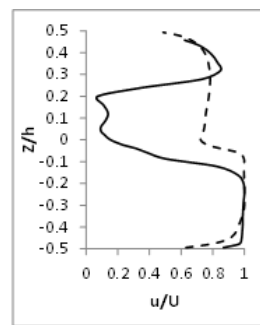

(e)

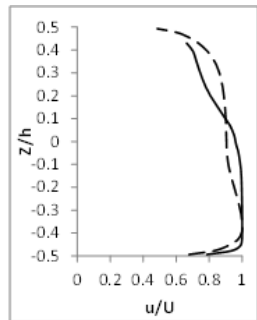

(h)
- - - - Damper 0 deg

Gambar 5. Grafik velocity profile masing-masing posisi cross-section berdasarkan $\mathrm{x} / \mathrm{D}_{\mathrm{h}}$ : a). $0^{\circ}$; b). $90^{\circ}$; c). -1 ; d).0; e).1; f).2 ;g).3; h).10; i).15

Pada gambar 4. secara umum bentuk profil kecepatan di sepanjang sisi upstream sampai downstream dijelaskan sebagai berikut: saat memasuki elbow, profil kecepatan sudah mengalami perkembangan sejauh $6 \mathrm{Dh}$, seperti pada gambar 5.(a) kecepatan pada sisi inner lebih besar dari pada sisi outer hal ini dipengaruhi oleh adanya perbedaan tekanan antara sisi inner dan outer bentuk profil ini akan sama sampai outlet elbow (gambar 5.(b)). Pada jarak $\mathrm{x} / \mathrm{D}_{\mathrm{h}}=-1$ sebelum melewati damper terjadi kerugian energi kinetik (kinetic energy losses) yang disebabkan oleh terbentuknya aliran sekunder di sisi inner elbow sehingga terdapat blockage effect seperti pada gambar 5.(c) akibatnya sebagian besar aliran akan mengalir pada sisi outer sehingga memiliki kecepatan yang lebih besar. Ketika aliran terganggu oleh laluan berupa damper seperti pada gambar 5.(d), terdapat perbedaan yang signifikan pada variasi kedua sudut damper, pada sudut $30^{\circ}$ terjadi percepatan pada sisi inner wall, hal ini disebabkan karena adanya penyempitan luas penampang, namun sebagian aliran yang mengalir pada sisi outer wall memiliki kecepatan yang rendah. Sedangkan pada sudut $0^{\circ}$ sisi yang memiliki kecepatan lebih tinggi adalah sisi outer , disebabkan pada sisi inner masih terdapat pengaruh aliran sekunder sebelumnya. Setelah melalui damper sejauh Dh terjadi recovery di sisi centerline, terlihat pada gambar 5.(e); (f); (g). Selanjutnya pada jarak $\mathrm{x} / \mathrm{D}_{\mathrm{h}}=10 \mathrm{~s} / \mathrm{d} 15$ kedua aliran tersebut sudah normal kembali .

3.2. Perbandingan Vektor Kecepatan Setiap Cross-Section Pada $\operatorname{Re}=2.05 \times 10^{5}$ Dengan Sudut Kemiringan $\alpha=0^{\circ}$ dan $30^{\circ}$

Pada sub-bab ini akan disampaikan visualisasi berupa vektor kecepatan di setiap cross-section yang posisinya telah ditunjukkan oleh gambar 3. Dari visualisasi aliran tersebut akan diperoleh perbandingan yang lebih jelas mengenai perilaku aliran yang terjadi pada rectangular duct secara tiga dimensi. Berikut ini hasil dari masingmasing cross-section yang diambil gambar vektor 
kecepatannya seperti yang terlihat pada gambar 6 dan 7

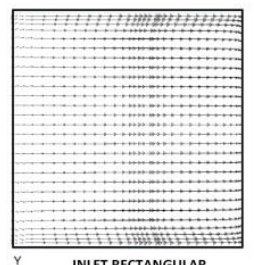

Y INLET RECTANGULAR

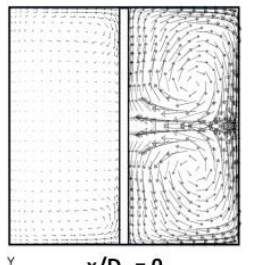

$x=\quad x / D_{h}=0$

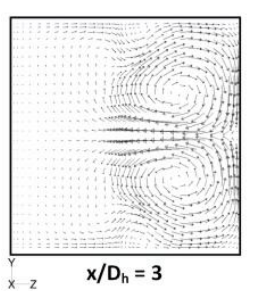

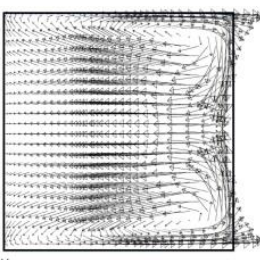

$y \quad$ OUTLET RECTANGULAR
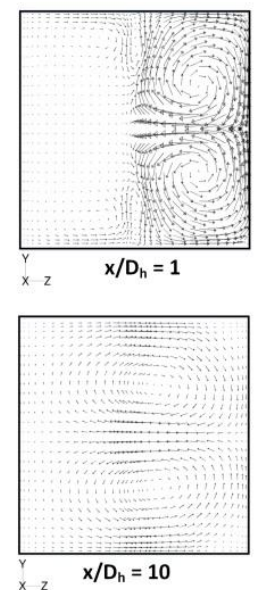

$x z \quad x / D_{h}=1$

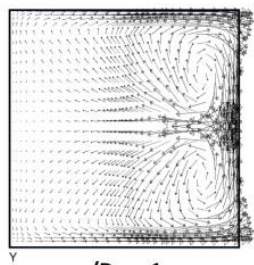

$x=x / D_{h}=-1$
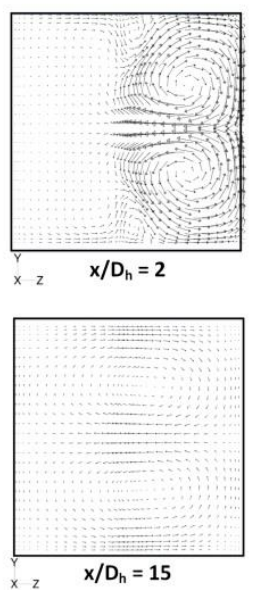

Gambar 6. Visualisasi vektor kecepatan di setiap cross-section untuk Re $=2.05 \times 10^{5} ; \alpha=0^{\circ}$

Berdasarkan gambar 6 dan 7 dapat terlihat visualisasi aliran dalam bentuk tiga dimensi dari inlet elbow sampai $\mathrm{x} / \mathrm{D}_{\mathrm{h}}=15$. Daerah outlet elbow di sisi inner wall dimana terjadi perlambatan disebabkan oleh terbentuknya aliran sekunder, sehingga hal ini berpengaruh terhadap velocity profile yang terlihat lebih kecil pada sisi inner-nya. Setelah aliran mengalir sejauh $10 \mathrm{Dh}$ aliran sekunder berangsur-angsur kembali mengikuti aliran utamanya, hal ini ditandai dari vektornya berbentuk titik, artinya vektor tersebut searah dengan sumbu $\mathrm{x}$.
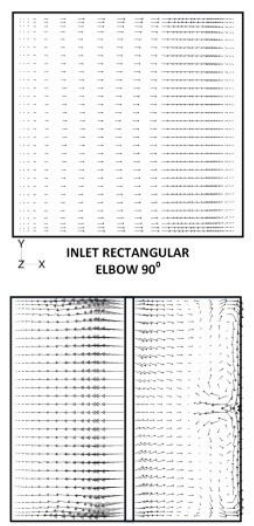

$x=x / D_{h}=0$

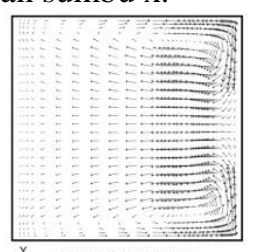

$Y$
$x z \underset{\text { OUTLET RECTANGULAR }}{\text { ELBOW } 90^{\circ}}$

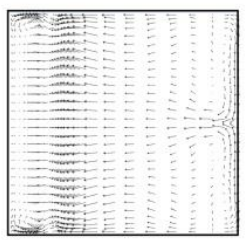

$x=x / D_{h}=1$

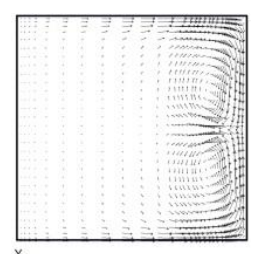

$y=\quad x / D_{h}=-1$
$x<2$

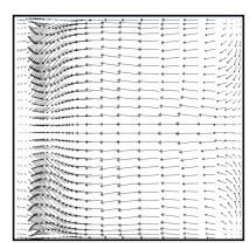

$x=\quad x / D_{h}=2$
Pada sudut bukaan $30^{\circ}$ dijumpai aliran sekunder pada sisi outer maupun inner di posisi $\mathrm{x} / \mathrm{D}_{\mathrm{h}}=0 \mathrm{~s} / \mathrm{d} 2$, hal itu disebabkan karena efek kerugian energi kinetik di sisi centerline yang mempengaruhi aliran didekat dindingnya.
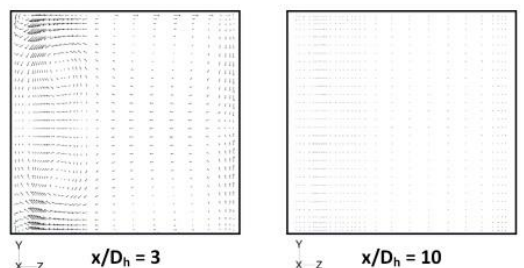

$y=x / D_{h}=10$
$x=2$

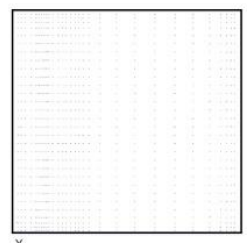

Gambar 7. Visualisasi vektor kecepatan di setiap cross-section untuk Re $=2.05 \times 10^{5} ; \alpha=30^{\circ}$

3.3. Perbandingan Distribusi Profil Kecepatan Pada Sudut Kemiringan $\alpha=0^{\circ}$ dan $30^{\circ}\left(\operatorname{Re}=8.2 \times 10^{5}\right)$

Berikut ini adalah gambaran umum velocity profile beserta kontur kecepatan yang mewakili besar kecepatan sepanjang aliran seperti pada gambar 8
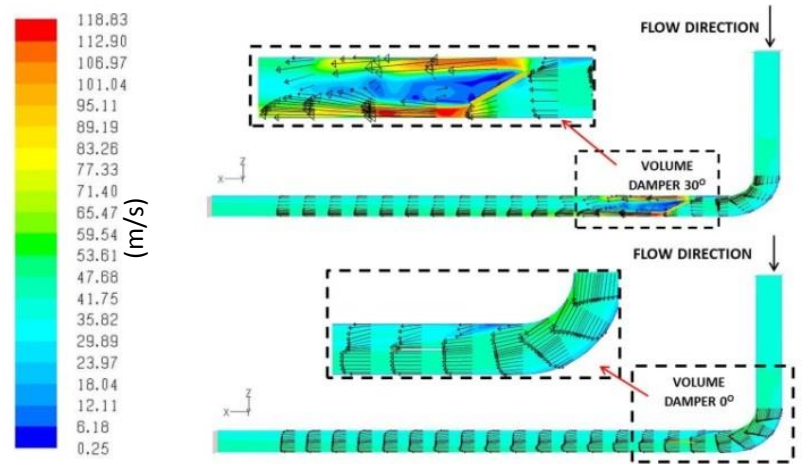

Gambar 8. Perkembangan velocity profile dan kontur kecepatan sepanjang aliran untuk $\mathrm{Re}=8.2 \times 10^{5}$

Setelah itu akan dibahas penjelasan analisa tentang bagaimana perilaku aliran secara dua dimensi dari upstream menuju downstream berupa grafik velocity profile dalam bentuk bilangan tak berdimensi, agar lebih detail dipaparkan dalam grafik perbandingan antara sudut bukaan $0^{\circ}$ dan $30^{\circ}$ sebagaimana yang tertera pada gambar 9.

Pada gambar 8 secara umum bentuk profil kecepatan di sepanjang sisi upstream sampai downstream dijelaskan sebagai berikut: saat memasuki elbow, profil kecepatan sudah mengalami perkembangan sejauh $6 \mathrm{Dh}$, seperti pada gambar 9.(a) kecepatan pada sisi inner lebih besar dari pada sisi outer hal ini dipengaruhi oleh adanya perbedaan tekanan antara sisi inner dan outer bentuk profil ini akan sama sampai outlet elbow (gambar 9.(b)).

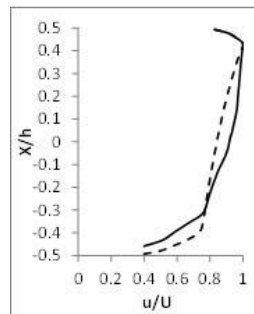

(a)

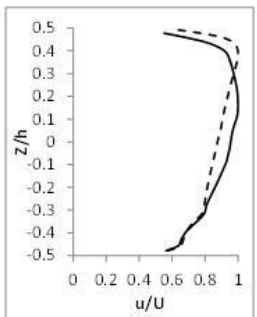

(b)

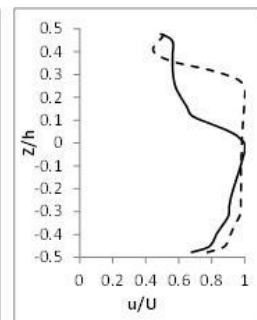

(c) 


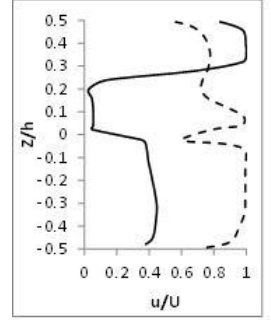

(d)

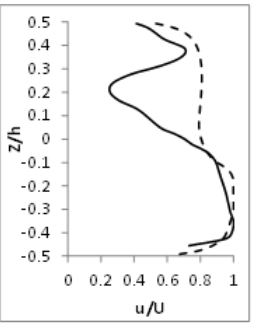

(g)

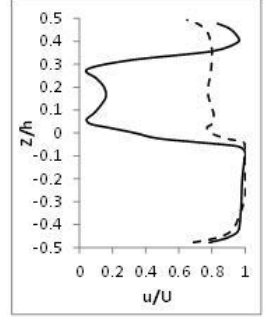

(e)

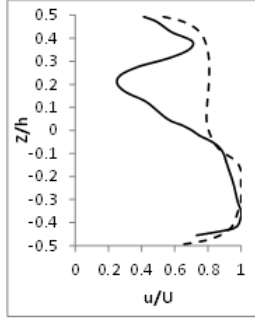

(h)

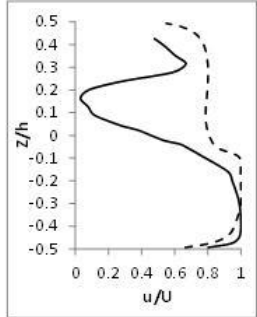

(f)

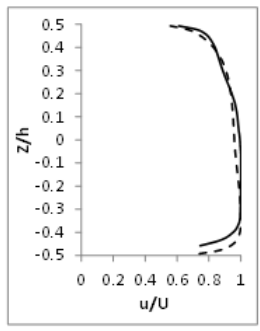

(i)
- - - - Damper 0 deg

Damper 30 deg

Gambar 9. Grafik velocity profile pada masing-masing posisi crosssection berdasarkan $\mathrm{x} / \mathrm{D}_{\mathrm{h}}$ : a). $0^{\circ}$; b) $.90^{\circ}$; c). -1 ; d). 0 ; e). 1 ; f). 2 ;g).3; h).10; i). 15

Pada jarak $\mathrm{x} / \mathrm{D}_{\mathrm{h}}=-1$ sebelum melewati damper terjadi kerugian energi kinetik (kinetic energy losses) yang disebabkan oleh terbentuknya aliran sekunder di sisi inner elbow sehingga terdapat blockage effect seperti pada gambar 9.(c) akibatnya sebagian besar aliran akan mengalir pada sisi outer sehingga memiliki kecepatan yang lebih besar. Ketika aliran terganggu oleh laluan berupa damper seperti pada gambar 9.(d), terdapat perbedaan yang signifikan pada variasi kedua sudut damper, pada sudut $30^{\circ}$ terjadi percepatan pada sisi inner wall, hal ini disebabkan karena adanya penyempitan luas penampang, namun sebagian aliran yang mengalir pada sisi outer wall memiliki kecepatan yang rendah. Sedangkan pada sudut $0^{\circ}$ sisi yang memiliki kecepatan lebih tinggi adalah sisi outer, disebabkan pada sisi inner masih terdapat pengaruh aliran sekunder sebelumnya. Setelah melalui damper sejauh Dh terjadi recovery di sisi centerline, terlihat pada gambar 9.(e); (f); (g). Selanjutnya pada jarak $\mathrm{x} / \mathrm{D}_{\mathrm{h}}=10 \mathrm{~s} / \mathrm{d} 15$ kedua aliran tersebut sudah normal kembali

\subsection{Perbandingan Vektor Kecepatan Setiap Cross-Section} Pada $\operatorname{Re}=8.2 \times 10^{5}$ Dengan Sudut Kemiringan $\alpha=0^{\circ}$ dan $30^{\circ}$

Penjelasan tentang terbentuknya aliran sekunder pada penampang tertentu akan dipaparkan lebih jelas pada pembahasan di sub-bab ini melalui gambar 10 dan 11.
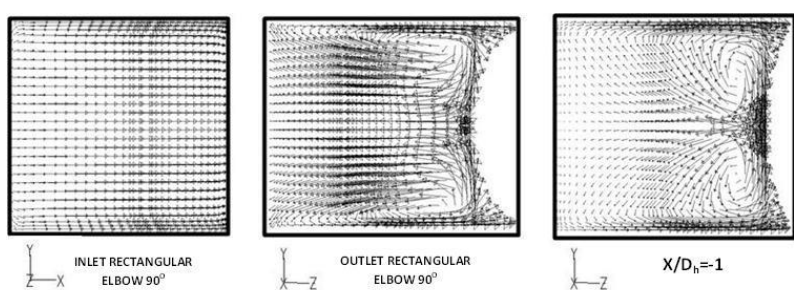
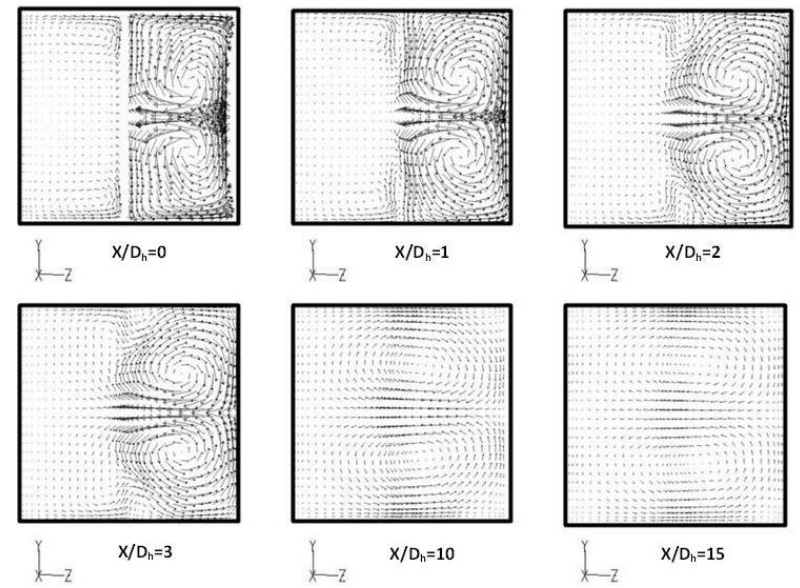

Gambar 10. Visualisasi vektor kecepatan di setiap cross-section untuk Re $=8.2 \times 10^{5} ; \alpha=0^{\circ}$
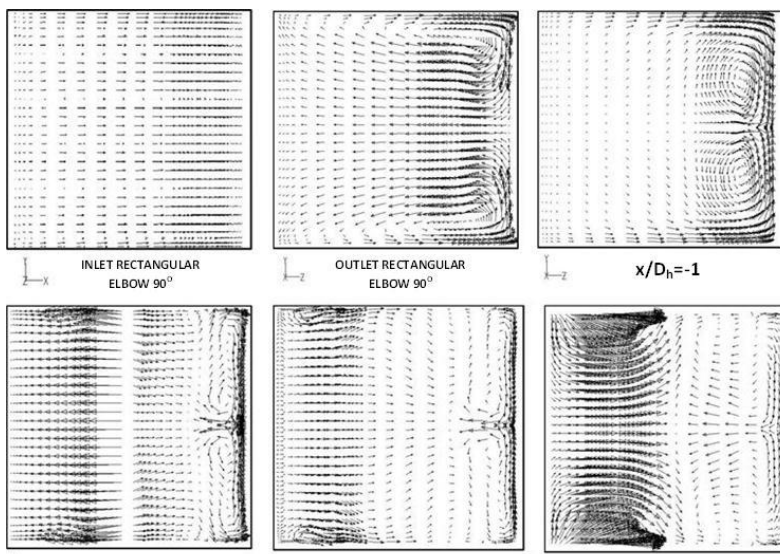

$\mathrm{x} / \mathrm{D}_{\mathrm{h}}=0$
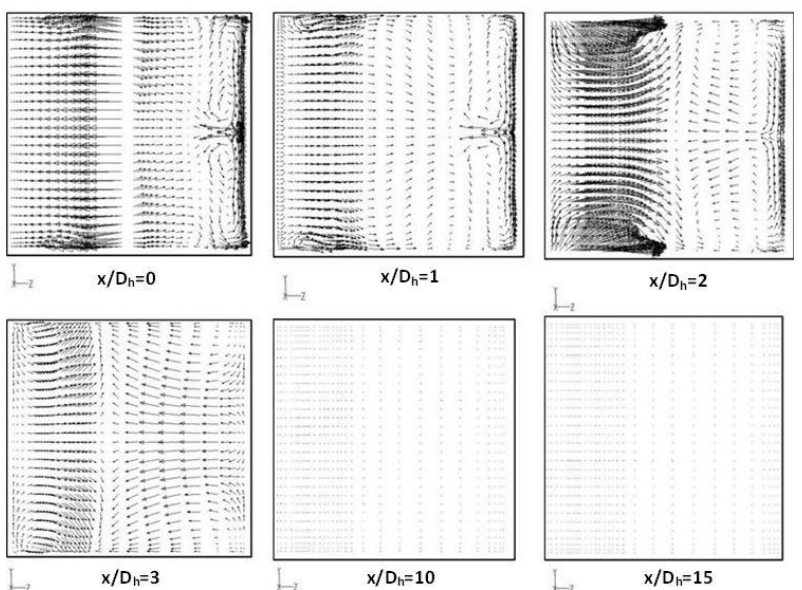

Gambar 11. Visualisasi vektor kecepatan di setiap cross-section untuk $\mathrm{Re}$ $=8.2 \times 10^{5} ; \alpha=30^{\circ}$

Berdasarkan gambar 10 dan 11 dapat terlihat visualisasi aliran dalam bentuk tiga dimensi dari inlet elbow sampai $\mathrm{x} / \mathrm{D}_{\mathrm{h}}=15$. Daerah outlet elbow di sisi inner wall dimana terjadi perlambatan disebabkan oleh terbentuknya aliran sekunder, sehingga hal ini berpengaruh terhadap velocity profile yang terlihat lebih kecil pada sisi inner-nya. Setelah aliran mengalir sejauh $10 \mathrm{Dh}$ aliran sekunder berangsur-angsur kembali mengikuti aliran utamanya, hal ini ditandai dari vektornya berbentuk titik, artinya vektor tersebut searah dengan sumbu x. Pada sudut bukaan $30^{\circ}$ dijumpai aliran sekunder pada sisi outer maupun inner di posisi $\mathrm{x} / \mathrm{D}_{\mathrm{h}}=0 \mathrm{~s} / \mathrm{d} 2$, hal itu disebabkan karena efek kerugian energi kinetik di sisi centerline yang mempengaruhi aliran didekat dindingnya.

\section{KESIMPULAN/RINGKASAN}

Dari hasil penelitian yang telah dibahas sebelumnya maka dapat diambil kesimpulan meliputi sebagai berikut : 
1. Adanya perlambatan aliran di daerah yang menghubungkan upstream dan downstream sesaat sebelum melalui damper untuk semua variasi sudut, hal ini disebabkan adanya blockage effect akibat terbentuknya aliran sekunder pada sisi inner wall dekat dinding, daerah ini memiliki momentum yang rendah.

2. Tidak ada pengaruh yang signifikan pada variasi kecepatan terhadap proses recovery aliran, melainkan proses recovery aliran sangat dipengaruhi variasi sudut bukaan damper $0^{\circ}, 10^{\circ}, 20^{\circ}, 30^{\circ}$

3. Pembentukan aliran sekunder pada sudut bukaan damper $0^{\circ}$ hanya terjadi pada sisi inner wall, sedangkan pada sudut bukaan damper $30^{\circ}$ aliran sekunder terbentuk pada sisi inner maupun outer wall.

4. Pada variasi sudut bukaan damper $0^{\circ}$ memiliki variasi range kecepatan yang paling rendah, sedangkan sudut bukaan damper $30^{\circ}$ memiliki variasi range kecepatan yang paling tinggi, hal ini disebabkan penyempitan luas penampang di daerah sekitar damper, dimana di daerah tersebut terjadi percepatan aliran.

5. Sudut bukaan damper $30^{\circ}$ merupakan sudut yang paling efektif untuk mempercepat proses recovery aliran dan menanggulangi timbulnya aliran sekunder yang terletak di dekat dinding.

\section{DAFTAR PUSTAKA}

[1] Danbon, F dan Solliec, C. 2000." Aerodynamic Torque of a Butterfly Valve-Influence of an Elbow on the Time-Mean and Instantaneous Aerodynamic Torque." Nantes: Ecole des Mines de Nantes, Dèpartement Systémes.

[2] Zaldhy L. P. P, Louis. 2015. "Studi Numerik Karakteristik Aliran Melalui Modified Octagonal U-Bend Dengan Dan Tanpa Guide Vane" Jurusan Teknik Mesin : ITS

[3] Rup, K., dan Sarna, P. 2011."Analysis of Turbulent Flow Through a Square-Sectioned Duct with Installed 90-degree Elbow". Cracow: Elsevier 